\title{
Válaszok a klímaváltozás kérdésére a fiskális és monetáris politika oldaláról
}

\section{Fiscal and Monetary Policy Responses to Climate Change}

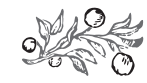

\section{Összefoglalás}

Franciaországban 2018 utolsó hónapjaiban minden hétvégén több tízezer ember vonult az utcákra. A tüntetések kiváltó oka az üzemanyagár és az azt sújtó környezetvédelmi adó emelése volt, amelyet a kormányzat a 2014-ben bevezetett jogszabályok értelmében szeretett volna tovább növelni. A francia példa is jól mutatja, hogy a klímaváltozás elleni intézkedések sok esetben jelentôs ellenállást váltanak ki a lakosság részérôl, miközben a globális felmelegedés egyre nagyobb veszélyt jelent. A tanulmány bemutatja, miként került a klímaváltozás egyre inkább a figyelem középpontjába, hogyan került be a környezetszennyezés és az azzal összefüggó klímaváltozás kérdése a közgazdaságtanba, illetve milyen válaszok születtek rá a gazdaságtudomány részéról. A szerzô ismerteti a fiskális és a monetáris politika számára rendelkezésre álló eszközrendszert a környezettel kapcsolatos negatív externáliák hatásának a csökkentésére, amelyben véleménye szerint mindkét szakpolitika részérôl a mostaninál sokkal aktívabb szerepvállalás szükséges.

Journal of Economic Literature (JEL) kódok: Q58, Q55, E52, E62

Kulcsszavak: klímaváltozás, fiskális politika, monetáris politika, zöld pénzügyek, Kuznets-görbe

BARTóк LÁszló doktorandusz, Szegedi Tudományegyetem Gazdaságtudományi Kar, Doktori Iskola (laszlo.bartok.1988@outlook.com). 
Bartók László: Válaszok a klímaváltozás kérdésére a fiskális és monetáris politika...

\section{Summary}

In the last months of 2018, every weekend tens of thousands of people demonstrated in the streets in France. The main reason for the demonstrations was a rise in fuel prices and the environmental tax levied on them by the government in an effort to further increase them as stipulated in the relevant 2014 act. The French example shows that in many cases the actions taken to counter climate change can trigger significant resistance from the society; while global warming presents an increasing threat to mankind. In the first part of the publication, a brief account is given of climate change coming into global focus in the past 20 years. Then the inclusion of environmental pollution and the related climate change into economics, and the responses are described, and the fiscal and monetary toolbox available for mitigating the effects of negative externalities related to the environment is presented and it is suggested that both must be involved more proactively in the fight against climate change.

Journal of Economic Literature (JEL) codes: Q58, Q55, E52, E62

Keywords: climate change, fiscal policy, monetary policy, green finance, Kuznets-curve

\section{A KLÍMAVÁltozÁS KÉRdéSÉNEK MEGJELENÉSE A 2O. SZÁZAD VÉGÉN}

A klímaváltozás kérdése a 20. század végén került egyre inkább a döntéshozók és ezzel együtt a közgazdászok figyelmének középpontjába. Az elsô számottevô előrelépés az 1997-es kiotói egyezmény volt. Még ha a szerzôdésben megfogalmazott célkitúzések nem is érték el a kívánt hatást, mégis közel 160 ország ratifikálta az egyezményt. A megállapodás 2005-ben lépett érvénybe, és céljai között szerepelt a szén-dioxid és további öt, üvegházhatású gáz mennyiségének csökkentése. Ennek értelmében az egyes országok és vállalatok számára szén-dioxid-kibocsátási kvótákat határoztak meg. Ha az adott vállalat a meghatározott kvótánál többet szeretne felhasználni, akkor a kevésbé környezetszennyezô üzletágakban tevékenykedô vállalatoktól úgynevezett széndioxid-kvótát tud vásárolni (Vermeend-Van der Ploeg-Timmer, 2008).

A kiotói egyezményt követôen a nemzetközi tudományos körökben egyre intenzívebb vita folyt a klímaváltozás kérdését illetôen, így egyes kutatók máig szkeptikusak a kérdést illetôen. Az ENSZ Éghajlatváltozási Kormányközi Testületének (UN Intergovernmental Panel on Climate Change - IPCC) megállapítása szerint azonban az emberi tevékenység 90\%-os bizonyossággal járul hozzá a klímaváltozáshoz, így globális szinten számos intézkedésre lenne szükség ahhoz, hogy csökkentsék az üvegházhatású gázok kibocsátását. Nicolas Stern, a Világbank egykori vezető közgazdászának a bábáskodása alatt jelent meg az úgynevezett Stern-riport, amely a klímaváltozás gazdasági hatásait vizsgálta. A jelentés szerint, ha a döntéshozók nem cselekednek időben, akkor a klímaváltozás miatt a világgazdaság teljesítménye akár 20\%-kal is csökkenhet (Stern, 2007). A globális felmelegedés ugyanis együtt jár olyan tényezókkel, mint például az 
áradások gyakoriságának a növekedése, amely akár százmillió embert kényszeríthet a lakhelye elhagyására. A pólusokon lévô jégsapkák elolvadása a tengerszint emelkedésével járhat, amely akár négymillió négyzetkilométer szárazföld elárasztását jelentheti, ami a világ lakosságának akár a 4\%-át is érintheti, ugyanis sok esetben olyan, a nemzetközi gazdaságban kulcsszerepet játszó nagyváros kerülhet víz alá, mint Amszterdam, London, Miami vagy New York. A Stern-riport szerint egyrészt szankcionálni kell a kibocsátókat, másrészt elótérbe kell helyezni az úgynevezett második generációs technológiákat azért, hogy elôsegítsük a tisztább közlekedési megoldások, a megújuló energiaforrások és az energiahatékony technológiák terjedését. Ehhez elkerülhetetlen a kutatás és fejlesztés előtérbe helyezése, amelyhez az egyes kormányoknak különbözó közpolitikai intézkedések révén kell hozzájárulniuk.

A fentiekkel kapcsolatban érdemes megemlíteni az úgynevezett környezeti Kuznets-görbét (EKC), amely szerint az üvegházhatású gázok mennyisége a gazdasági növekedés kezdeti szakaszában növekszik a levegóben, majd miután az adott ország elér egy bizonyos fejlettségi szintet, akkor ezen gázok kibocsátása csökken. Így kezdetben a környezet és a levegő minôsége romlik a gazdasági növekedés által, majd idővel újra javulni kezd. A jelenséget több módon próbálják magyarázni, így egyesek szerint míg eleinte az energiaigényes ipari szektor dominál a nemzetgazdaságon belül, addig idôvel egyre nagyobb szerepet kap a tercier szektor. Más elméletek szerint az emberek eleinte a saját szükségleteik kielégítésére költenek, és egy bizonyos jóléti szint elérése után kezdi érdekelni óket a környezetvédelem. Brock és Taylor (2004) szerint a fenti elméletek nem adnak kielégítô magyarázatot a környezeti Kuznets-görbére, és meglátásuk szerint az általuk kidolgozott, úgynevezett „zöld” Solow-modell bizonyítja azt. Véleményük szerint az EKC elsôsorban a szennyezés csökkenéséhez és a technológiai innovációk fejlődéséhez kapcsolódik, amely eleinte a gazdagabb államokban nyer teret, majd idôvel megjelenik a fejlődő országokban is. Így mivel az üvegházhatású gázok kibocsátása nem ismer határokat, ezért célszerú lenne a fejlődô országok számára is elôtérbe helyezni az alacsony károsanyag-kibocsátással járó ipari technológiákat és a megújuló energiaforrások használatát.

Stern (2004) kutatásában szintén megkérdőjelezi a környezeti Kuznets-görbe érvényességét, ugyanis a jelenlegi adatok azt mutatják, hogy a fejlődô országok sok esetben már rögtön a fejlett országokban alkalmazott környezeti szabályozásokat veszik át, melyeket így sokkal rövidebb idô alatt és sok esetben sokkal hatékonyabban implementálnak. Nem beszélve arról, hogy bizonyos szabályozások egyes esetekben még szigorúbbak is, mint a fejlett országokban. Ezt jól példázza Kína esete. Peking 2015ben egy szigorú környezetvédelmi szabályozást vezetett be, melyet 2017-ben újabb követett. A rendelet szerint a hatóságok korlátlan nagyságú büntetést szabhatnak ki azon vállalatok számára, amelyek nem tartják be a kötelezô szabályozást, miközben az érintett cégek neve médianyilvánosságot kap. Nemcsak a vállalati szektor részéről vár erôfeszítéseket az új szabályozás, de a törvény az egész kínai lakosság számára környezettudatosabb életmódot ír elő (Khan-Chang, 2018).

Nemzetközi szinten az elmúlt években a legnagyobb áttörést a 2015-ös párizsi éghajlatvédelmi egyezmény (COP 21) jelentette, amelyet 194 ország írt alá, melyból már 
Bartók László: Válaszok a klimaváltozás kérdésére a fiskális és monetáris politika...

181 ratifikált is, köztük a három legnagyobb szén-dioxid-kibocsátónak számító állam: Kína, az Egyesült Államok és India. Az egyezmény három fontos vállalást tartalmaz:

„a) A globális átlaghómérséklet emelkedésének jóval $2{ }^{\circ} \mathrm{C}$ alatt tartása az iparosodás előtti szinthez képest, majd az erófeszítések folytatásaként a hómérséklet emelkedésének $1,5^{\circ} \mathrm{C}$ alatt tartása az iparosodás elôtti szinthez képest, elismerve, hogy ez jelentôsen csökkenti az éghajlatváltozás kockázatait és hatásait;

b) Az éghajlatváltozás kedvezôtlen hatásaihoz történô alkalmazkodás képességének növelése, az éghajlatváltozással szembeni ellenálló képesség és az alacsony üvegházhatásúgáz-kibocsátással járó fejlốdés elôsegítése, miközben ezek a folyamatok nem fenyegetik az élelmiszergyártást;

c) A pénzáramlások következetessé tétele, hogy az alacsony üvegházhatásúgáz-kibocsátással járó és az éghajlattal szemben rugalmas fejlôdési lehetôségek felé haladjanak" (UN, 2015).

A fent bemutatott célkitúzések csupán a fiskális és a monetáris politika összehangolásával érhetôk el. Mielôtt azonban megvizsgálnánk a rendelkezésre álló közpolitikai eszközöket, röviden felvázolom, hogyan került a környezetszennyezés kérdése a közgazdaságtan figyelmébe.

\section{A KÖRNYEZETVÉDELEM ÉS A KLÍMAVÁLTOZÁS KÉRDÉSÉNEK MEGJELENÉSE A KÖZGAZDASÁGTANBAN}

A környezetszennyezés és annak gazdasággal kapcsolatos kérdéskörét Arthur Pigou vezette be a közgazdasági gondolkodásba az 1920-ban írt Economics of Welfare (Jóléti közgazdaságtan) címú könyvében. Hogy megértsük a környezetszennyezés és a gazdaság kapcsolatát, érdemes röviden kitérni a Cambridge-i Egyetem professzora által bevezetett externália fogalmára, amely egy gazdasági szereplő tevékenysége által felmerülő, nem szántszándékkal okozott olyan hatás, amely piaci ellentételezés nélkül hatással van a gazdaság többi szereplőjének helyzetére is. Ennek értelmében beszélhetünk pozitív (elônyös) és negatív (káros) externáliákról (Pataki-Bela-Kohlheb, 2003).

Ilyen (negatív) externália a környezetszennyezés is, amely „a társadalom számára jóléti veszteséget okoz, amit a piac korrekciójával, kormányzati beavatkozás révén lehet megszüntetni” (Pataki-Bela-Kohlheb, 2003:6). Ez az állami beavatkozás nem jelent mást, mint a kormányzat által kivetett adót, melyet a szakirodalom rendszerint csak Pigou-féle szennyezési adónak nevez. Az ilyen típusú adó célja, hogy „a nem hatékony erôforrás-felhasználás [...] megszúnjön, s a gazdaságpolitika ún. Pareto-hatékony javulást elérve, a társadalmat a korábbinál magasabb jóléti szintre juttassa” (Pataki-Bela-Kohlheb, 2003:6).

Sokáig az a nézet uralkodott a Pigou-féle adóval szemben, hogy az jelentôs mértékben rontja a vállalatok és a nemzetgazdaság versenyképességét. Tudniillik, az adó kivetése után az adott termék megdrágul, hiszen a termelési költségek nônek, így „a korábban a társadalomra hárított externális költségeket az új helyzetben a szennyezés minden egysége után meg kell fizetnie" (Pataki-Bela-Kohlheb, 2003:7). Így meglehet, hogy a közteher a környezet minôségének javulása miatt jóléti nyereséggel jár, de 
az adott termék vagy szolgáltatás árának növekedése miatt annak fogyasztása is csökken, ami már jóléti veszteséget okoz, amely rendszerint meghaladja a nyereséget, így a „gazdaság szereplôi, a termelôk és a fogyasztók növekvő költségeket, árakat érzékelnek” (Pataki-Bela-Kohlheb, 2003:7). Weisbach (2012) szerint „a Pigou-féle adónak tulajdonképpen egyfajta megelôzó eszköznek kellene lennie, és a környezeti adó mértéke nem lehet sem kisebb, sem magasabb, mint a környezetterhelés határköltsége. Ez azt jelenti, hogy az államnak fel kell mérnie, elôzetes információval kell rendelkeznie a környezetterhelés majdani mértékéról” (Szlifka, 2014:2).

A környezetvédelmi adók bevezetése kapcsán jelentős áttörést hozott a versenyképesség Michael Porter általi újszerú, úgynevezett dinamikus újraértelmezése, melyet az 1990-ben megjelent The Competitive Advantage of Nations (A nemzetek versenyelőnye) címú könyvében fejtett ki. A Harvard Business School professzora szerint a nemzetközi versenyképesség kulcsa valójában a vállalatok és a nemzetgazdaságok gyors alkalmazkodási és megújulási képességében rejlik. Ennek köszönhetôen ugyanis sokkal gyorsabban tudják kiaknázni a változó fogyasztási preferenciákat. Így Porter szerint sokkal fontosabb a vállalatok innovációs képessége, mint a rendelkezésre álló termelési tényezôk bősége, sôt éppen ezen utóbbiak szúkössége követeli meg az innovációra való törekvést. Így a mi esetünkben, azaz a környezetpolitikát illetôen a kormány a szennyezési adókon keresztül üzen a vállalatok felé, hogy a rendelkezésre álló erőforrások végesek, amely így innovációra sarkallja a vállalkozásokat (Porter, 1990). Ez a hatékonyság folyamatos növekedésével jár, amely „hatékonysági nyereségek ellensúlyozhatják a környezetpolitikai szabályozás teljesítésének statikus költségeit" (Pataki-Bela-Kohlheb, 2003:3). Márpedig az innovatívabb vállalatok - és nemzetgazdaságok - hosszabb távon sokkal alkalmazkodóképesebbek, így hosszú távú piaci előnyre tehetnek szert.

A Pigou-adó előnye, hogy egyszerre két módon is csökkenti a társadalmi határköltséget. Egyrészt az adóbevételek által mérsékli a társadalmi költséget, másrészt, árrugalmasságtól függóen, próbál eltántorítani a negatív externáliáktól, miközben a Pigou-adó gyenge pontja, hogy „két ellentétes célt szolgál”, azaz egyszerre kellene visszaszorítania a negatív externáliákat, miközben költségvetési bevételeket is biztosítania kellene (Kutasi-Perger, 2014). „Az externália és a költségvetési bevétel közötti átváltás (trade-off) múködési mechanizmusa a következô: ha nem sikerül visszaszorítani az externáliát, akkor fenntartható lesz az adóbevétel, és persze nem szúnik meg a társadalmi költség. Ha viszont sikerül visszaszorítani az externáliát, akkor megszúnik az adóalap, így az erre épülô adóbevétel is. Utóbbi eset tompítható az adókulcsok növelésével, ami persze még hatékonyabban csökkentheti az adóalapot” (Kutasi-Perger, 2014:112).

\section{A FiskÁlis POLITIKA SZÁMÁRA RENDELKEZÉSRE Álló ESZKÖZÖK}

A zöld- vagy környezetvédelmi adók részét képezik az egyes kormányzatok által használt környezetvédelmi eszköztárnak. A zöldadók azon közterheket jelentik, melyek környezetvédelmi szempontból fontosnak minôsülnek. Ezen adók körébe tartoznak 
Bartók László: Válaszok a klímaváltozás kérdésére a fiskális és monetáris politika...

az energiatermékekre, a gépjármúvekre, a mért vagy becsült károsanyag-kibocsátásra, a természeti erőforrásokra kivetett közterhek. Ez alól kivételt képeznek a környezetre káros termékekre kivetett forgalmi adók.

A szakirodalom szerint a zöldadók bevezetése nemcsak azért hasznos, mert csökkenti a környezetszennyezést, hanem azért is praktikus megoldás, mert ez sok esetben együtt jár a munkákat terhelô adók csökkentésével (Vermeend-Van der PloegTimmer, 2008). Ezt nevezik az úgynevezett „kettős jutalomnak” (double dividend). Így az Eurostat adatai szerint 1980 és 2001 között az egyes uniós kormányzatok egyre nagyobb mértékben hagyatkoztak a zöldadók bevezetésére, miközben jelentôs adóreformok keretein belül mérsékelték a munkákat terhelő adók nagyságát. Ez egybecsengett az Európai Unió Lisszaboni Szerződésében meghatározott célokkal, amely szerint nemcsak az ökológiai értelemben fenntartható jövốt kell szem elôtt tartaniuk a tagállamoknak, hanem a versenyképességet és a növekedést is, ami együtt jár a munkát terhelő adók nagyságának a csökkentésével.

A zöldadók használata több módon is hozzájárulhat az ökológiai átmenet mérsékléséhez. Így például az üzemanyagokra kivetett adók hosszabb távon csökkentik annak keresletét. Jóllehet, rövid távon az üzemanyagok kereslete rugalmatlan, így elsô látásra ezen energiahordozóra kivetett adó nem éri el a kitúzött ökológiai célt, nem hatékony. Stern (2007) azonban kimutatta, hogy hosszú távon az üzemanyag keresletének árrugalmassága magas, így például, ha az európai országok követték volna az Egyesült Államok példáját, és nem vezettek volna be az üzemanyagokra „zöldadót”, akkor annak kereslete a jelenlegihez képest kétszerese lenne az öreg kontinensen.

Másrészt a zöldadók sokkal hatékonyabban járulnak hozzá az energiatakarékos technológiák elterjedéséhez, mint a különféle környezetvédelmi és energiahatékonysági szabályozások. Tudniillik, míg a különbözô elôírások és szabályozások semmilyen „jutalmazással” nem járnak, addig egy zöldadókra épüló adórendszer jelentôs impulzust adhat a vállalatok számára ahhoz, hogy csökkentsék az energetikai kiadásaikat. Az ökológiai átmenet csökkentése érdekében a piacközpontú megközelítés az úgynevezett „répa és bot modellen” alapul, amelynek alapvetó célja az, hogy a vállalatok és magánszemélyek „jutalmat” kapnak, ha jól „viselkednek”, viszont büntetést, ha roszszat cselekednek. Ezzel egyrészt az ökológiai adókkal kapcsolatos aggályokat el lehet oszlatni, másrészrôl pedig a pozitív ösztönzók révén hamarabb mobilizálni lehet az embereket. A szennyezés megakadályozása vagy csökkentése mellett a kormányoknak célszerú felgyorsítani a környezetbarát technológiák terjedését is, amelyek - ha egy jól felépített közpolitikai rendszerrel párosul - nagymértékben stimulálni tudják a környezetvédelemmel kapcsolatos kutatás-fejlesztési tevékenységet, amely új piacokat s így új lehetôségeket nyit meg a vállalatok számára.

Az egyes zöldadók közül az egyik legnépszerúbb az úgynevezett energiahasználatra kivetett adó. Ebben az esetben az energiahordozó maga jelenti az adóalapot, ugyanis annak használata során közvetlenül a fogyasztóra lehet kiróni a közterhet. Fontos, hogy az adó mindenképp csak az energiahordozókra (pl. gázolaj, benzin, szén, természetes gázok, olaj, koksz vagy fútőolaj) vonatkozik, így bármilyen egyéb alapanyag vagy nyersanyag fogyasztására nem hatályos a közteher beszedése. Az adó nagyságá- 
nak megállapítása általában a megtermelt energia vagy az adott energiaforrás által kibocsátott szén-dioxid mértékének az alapján történik. Az adó beszedése az egyes energiaforrásokat illetôen eltérô, így például az üzemanyagok esetében a megfizetése a fogyasztási adóval egyszerre történik (Vermeend-Van der Ploeg-Timmer, 2008).

Az energiafogyasztásra kivetett adóval kapcsolatban érdemes megemlíteni Bureau (2011) tanulmányát, aki az üzemanyagra kivetett „szénadó” hatását vizsgálta 2003 és 2006 között a francia lakosság körében. Számításai szerint a robbanómotoros jármúvel rendelkezô háztartások évente átlagosan 79 eurónak megfelelô összeget vesztettek az adó bevezetésével. A megfizetett közteher nagysága a jövedelem növekedésével emelkedik, így míg az elsô, legszegényebb kvantilisbe tartozó, személygépkocsival rendelkezô háztartások 71 eurót vesztettek évente, addig a társadalom leggazdagabbjai már 88 eurót. Ha az egyes háztartások bevételeinek az arányában vizsgáljuk az adó mértékét, akkor azonban már a legszegényebb háztartások vesztenek a legtöbbet, ugyanis míg ôk a bevételük 6,3\%o-ét fordítják a közteher megfizetésére, addig a módosabb háztartások csupán 1,9\%o-ét. Bureau földrajzi alapon is vizsgálta az adó hatását, így a szénadó legnagyobb kárvallottjai az elővárosokban és a vidéki régiókban élô háztartások, amelyek sokkal többet vesztenek, mint a városi és külvárosi zónákban lévók. Tudniillik, míg az utóbbi kategóriákba tartozó lakosok számára alternatív közlekedési lehetôségek állnak rendelkezésre (pl. tömegközlekedés, kerékpár) - miközben átlagosan jóval kisebb távolságokat is kell vezetniük -, addig a vidéki és elővárosi lakosság (valós alternatíva híján) nem tudja hanyagolni a mindennapi gépkocsihasználatot. Így azon, elsố kvantilisbe tartozó lakosok, akik az elôvárosi vagy vidéki zónában élnek, 90\%-kal többet vesztettek (72 euró), mint azok, a szintén az elsố kvantilisbe tartozó háztartásokban élók, akik a városi területeken laktak (38 euró). Bureau szerint az adó által fellépó torzítást leginkább úgy lehet orvosolni, ha a szénadóból befolyó bevétel egy részét visszatérítjük az adófizetôknek. Ebben az esetben a család nagyságán alapuló („size-based” recycling) megoldás bizonyult a legprogresszívebb megoldásnak. Ezt követi a még szintén progresszív megoldásnak számító eset, ha minden háztartás számára egyenló összeget térítünk meg (flat recycling). A jövedelmen alapuló visszatérítés már erôsen regresszív hatást mutat Bureau modelljében, azaz a módosabb háztartások nyernek, miközben a szegényebbek vesztenek.

Az energiafogyasztást illetôen további lehetôség az úgynevezett kötelezô energiaadó, amellyel elsôsorban a háztartásokat és a kis- és középvállalkozásokat célozzák meg. Ezzel az adófajtával csökkenteni lehet annak kockázatát, hogy míg a nagyvállalatok energiakibocsátását egyoldalú szerzôdések biztosítják, addig a kkv-szektor és a háztartások ki tudják kerülni ezen adó megfizetését, és így nem járulnak hozzá az ökológiai átalakulás mérsékléséhez. Ennek az adónak tehát az a célja, hogy azokat a célcsoportokat érje el, amelyeket nehéz vagy szinte lehetetlen megcélozni hosszú távú nemzetközi egyezményekkel. Ebben az esetben az adót közvetlenül a szolgáltató fizeti ki, amely azonban beépíti az adó összegét a kiszámlázott összegbe, azaz a fogyasztó magasabb árak formájában fizeti meg a közterhet.

Nemcsak a fogyasztást lehet ösztönözni fiskális politika útján, hanem a technológiai innovációt, azaz a megújuló energiaforrások használatát is. Ilyen például a válla- 
latok számára nyújtható, úgynevezett gyorsított értékcsökkenés, amely során az állam a vállalkozónak lehetôséget biztosít arra, hogy leírja az energiatakarékos termelést elôsegítô eszköz értékcsökkenésének az értékét a befizetett adóból. Az intézkedés célja, hogy felgyorsítsa a technológiai innovációt, és elósegítse az új, környezetkíméló technológiai megoldások minél gyorsabb és egyszerúbb terjedését. A gyorsított értékcsökkentés mellett további megoldás az energiatakarékos technológiai megoldások - bizonyos százaléka - után kérhetô adójóváírás, amelynek nagysága általában a befektetés méretétől függ.

Végül pedig az egyes kormányok további közpolitikai megoldások révén növelhetik a lakosság és a vállalatok környezettudatosságát is. Így Vermeend et al. (2008) nyomán az alábbi lehetôségeket különböztethetjük meg:

- Tömegközlekedés támogatása: bizonyos kereteken belül a munkáltató leírhatja az adójából a munkavállalói tömegközlekedéssel kapcsolatos költségeit. Alternatív megoldás, ha a munkavállaló által fizetett jövedelemadóból vonják le az említett összeget.

- Carpooling vagy telekocsi: a carpooling olyan „utazási módot jelent, amely során a jármúvezető felkínálja saját tulajdonú személygépkocsijának szabad helyeit más utasok [...] számára. Így közös gépkocsihasználat, jármúmegosztás valósul meg” (Gyürüs et al., 2008:1). A munkáltatók ösztönözni tudják a munkavállalókat, hogy használják ki a carpooling lehetôségét, azáltal, hogy a megtett útvonallal arányos adómentes támogatást kap az összes olyan alkalmazott, aki részt vesz a carpoolingban.

- Távmunka: a digitális technológia fejlődése lehetôvé teszi, hogy a munkavállaló a hét egy vagy több napján a munkája egy részét otthonról végezze. A távmunkának köszönhetôen mérséklődik az ingázók száma, ami így együtt jár az autóhasználat csökkenésével is. Másrészrôl Bloom et al. (2015) kutatásai kimutatták, hogy a távmunka a munkavállalók hatékonyságát is növeli legalább 12\%-kal azokhoz képest, akik irodában dolgoznak. A munkavállalók ugyanis kevesebb betegszabadságot vesznek ki, csökken a kávészünettel eltöltött idó hossza, nem beszélve arról, hogy a nyugodt munkakörnyezet növeli az alkalmazott hatékonyságát.

- Céges kerékpár: a kerékpáros munkába járás ösztönzését elő lehet segíteni azzal is, hogy az állam lehetôséget biztosít arra, hogy munkáltató adómentesen vásároljon kerékpárt munkavállalói számára.

A fenti felsorolást azonban érdemes kiegészíteni egy, a korunkban egyre divatosabb támogatási formával: az elektromos autók után kapható kedvezménnyel is, amely nemcsak vállalatok, hanem magánszemélyek számára is elérhetô. Az elektromos autók használatuk során nem bocsátanak ki káros anyagot, így az egyes kormányok - bízva a zéró károsanyag-kibocsátásban - számos módon próbálják meg fellendíteni e jármúvek keresletét. Ezen autók ára - az akkumulátorcsomag miatt - azonban jelentős mértékben meghaladja a hasonló kategóriába tartozó, robbanómotoros gépjármúvekét. Nem beszélve arról, hogy használatuk is korlátozottabb, ugyanis az ilyen típusú autók hatótávolsága nagyságrendekkel elmarad a robbanómotoros társaiktól.

Az elektromos autókat illetôen az egyik legrégebbi és legszélesebb körú támogatási rendszerrel Norvégia rendelkezik. Olson (2015) a norvég elektromos autók után járó támogatási rendszer pénzügyi és környezeti költség-haszon elemzését végezte 
el. Számításai szerint a norvég autóflotta elektromos átállásából származó környezeti haszon pénzügyi értéke kisebb, mint az állam által nyújtott támogatások költsége. A helyzetet csak tovább árnyalja, hogy Norvégia így is a legideálisabb vizsgálati országnak számít, ugyanis itt az energiatermelés nagy részét vízerőmúvek adják, míg a világ legtöbb országában az elektromos áram elóállítása szénalapú erômúvekben történik. További probléma, hogy az elektromos autók előállítása 50-125\%-kal nagyobb szén-dioxid-kibocsátással jár, mint a hagyományos, robbanómotorral szerelt jármúvek gyártása, miközben a töltôhálózat kiépítése és annak árammal történô ellátása is további költséget - és szén-dioxid-kibocsátást - jelent. Olson továbbá figyelmeztet arra is, hogy az elektromos autók széles körú elterjedése az állam számára egyre nagyobb bevételkiesést jelent, hiszen a robbanómotoros autók száma csökken, ami együtt jár a hozzájuk kapcsolódó adó- és egyéb bevételek zsugorodásával (jövedéki adó, forgalmi adó stb.). Ez jól rímel a Kutasi és Perger (2014) által már korábban bemutatott problémára, hiszen itt kvázi a robbanómotorral szerelt gépjármúveket sújtja a „Pigou-adó” (ami ebben az esetben a forgalmi adó, vám stb. formájában jelenik meg), szemben a kvázi adó- és költségmentesen használható elektromos jármúvekkel. Olson véleménye szerint így elsôsorban nem a keresleti, hanem a kínálati oldalt kellene támogatniuk a kormányoknak, azaz innováció és technológiai fejlesztések támogatását kellene előtérbe helyezni, amely elôsegítheti a hosszú hatótávval rendelkezô elektromos autók megjelenését, és a gyártás során keletkezô szén-dioxid-kibocsátást is mérsékelni lehetne.

\section{A KÖZPONTI BANKOK SZEREPE A KLÍMAVÁlTOZÁS ELLENI K ÜZ D ELEMB EN}

A klímaváltozás kérdése egészen mostanáig távol állt a központi bankoktól. Az ortodox monetáris politika szellemében az 1980-as és 1990-es évektől kezdve a jegybankok nagy részének az egyetlen és legfontosabb célja az árstabilitás elérése és fenntartása lett, így nemhogy az éghajlatváltozás kérdése, de még a pénzügyi stabilitás, a gazdasági növekedés elôsegítése, illetve a foglalkoztatottság bôvülésének a támogatása sem tartozott sok jegybank kiemelt céljai közé. A pénzügyi stabilitás feladását az is jól mutatja, hogy a központi bankok nagy része a pénzügyi rendszer felügyeletét kiszervezte más hatóságok felé, és kizárólag az árstabilitás fenntartására koncentrált.

A 2008-as válság után azonban egyértelmúvé vált, hogy a monetáris politikának nemcsak az árstabilitásra kell fókuszálnia, hanem emellett a pénzügyi stabilitásra is nagyobb mértékben kell összpontosítania (IMF, 2011). A világválság óta ugyanis több szakember (Eichengreen et al., 2011) - köztük az ENSZ fenntartható fejlődéssel foglalkozó szakértôi (UN, 2017) - is a központi bankok feladatainak bôvítése mellett kardoskodik, és így az árstabilitást már nem az egyetlen elérendó célnak tartják. Ebben a kibóvített szerepkörben többek között helyet kap a környezetvédelem és a fenntartható fejlődés is, hiszen a klímaváltozás egyre nagyobb kockázatot jelent a pénzügyi stabilitásra nézve. The Economist Intelligence Unit (2015) által készített tanulmány arra a megállapításra jutott, hogy ha a legrosszabb forgatókönyv valósul meg a globális 
felmelegedést illetôen, akkor a pénzügyi szektor szereplői akár 13,8 billió dolláros veszteséget is elkönyvelhetnek, amely a világ pénzügyi eszközeinek 10\%-át jelenti. Így az ENSZ szakemberei szerint a jegybankok jelenlegi monetáris politikai céljait ki kell bôvíteni a környezetvédelemmel és a fenntartható fejlődés elôsegítésével, ugyanis mint a késóbbiekben látni fogjuk - ha ezeket a jegybankok nem építik be a célkitúzéseik közé, akkor azok közvetett módon jelentôs hatással lehetnek az ár- és a pénzügyi stabilitásra. Az ENSZ szakértői az 1. ábrának megfelelóen építenék fel a 21. századi jegybankok eszköztárát és célkitúzéseit.

1. ábra: A jegybanki eszközök, köztes és végsố pénzügy-politikai célok az ENSZ fenntartható fejlődéssel foglalkozó szakértői szerint

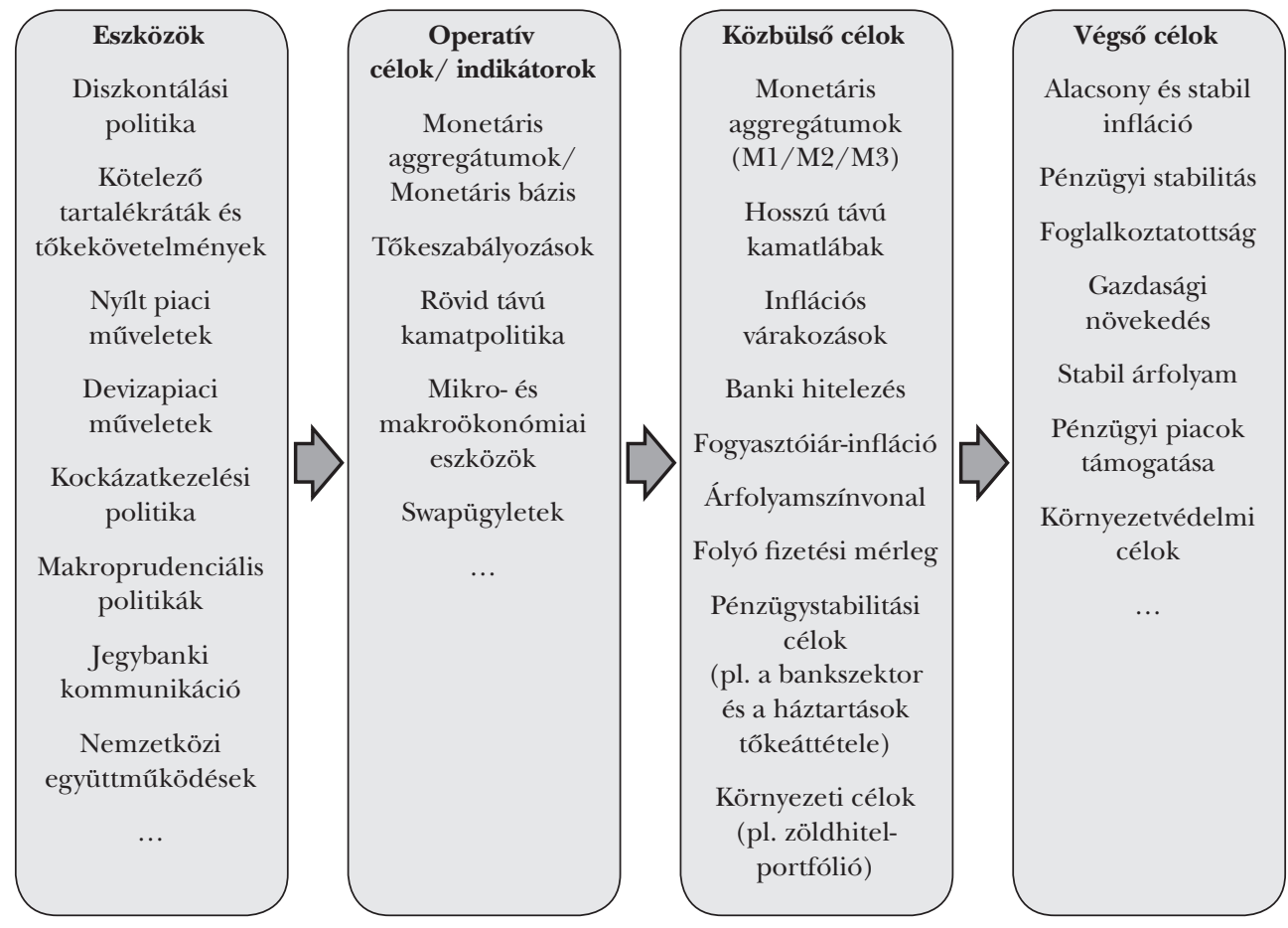

Forrás: UN, 2017

A jegybankok klímaváltozással szembeni elkötelezettségét mutatja, hogy a 2015 decemberében megrendezett COP 21 konferencia már a jegybankokat és a pénzügyi felügyeleti hatóságokat is egyre nagyobb mértékben mozgósította ezen a téren. A konferenciát megelőzôen, 2015 szeptemberében összeült a G20 Financial Stability Board (FSB), amely során megkezdődtek a tárgyalások a kormányzati és a magánszektor szakemberei között a klímaváltozással kapcsolatos kockázati tényezôkrôl. Nem sokkal később Mark Carney, az FSB vezetője és egyben a brit jegybank elnöke bejelentette, hogy az FSB e kockázati tényezôk tanulmányozására szakosodott munkacsoport felállítását javasolja, melynek hivatalos megalakulására végül a Párizsban megrendezett 
COP21-en került sor. Ezzel a lépéssel a pénzügyi szabályozás a klímaváltozás elleni harc egyik fontos szereplőjeként lépett elô.

A Bank of England jelentése alapján az ENSZ szakemberei a jegybankok klímaváltozás elleni küzdelemben való részvételét három fó tényezóvel magyarázzák (Bank of England, 2015b):

1. A globális felmelegedés és a szélsôséges időjárás jelentős pénzügyi és makroökonómiai kockázatokat tartogat, amelyek hatással vannak a nyersanyag-, az élelmiszer- és az energiaárakra is. Mindez pedig befolyásolja a maginfláció mértékét, így a klímaváltozás implicit módon hat az árstabilitásra. A pénzügyi rendszert érintő kockázatot illetôen a Bank of England három kategóriát különböztet meg, úgymint az átmeneti, a fizikai és a felelôsségbiztosításhoz kapcsolódó klíma- vagy környezetváltozással kapcsolatos kockázat.

- Átmeneti (transitional risk) kockázat: A klímaváltozás és annak hatásának a mérséklése a kormányzatok részéről egyre drasztikusabb közpolitikai megoldásokat, míg a háztartások és a vállalatok részérôl folyamatos alkalmazkodást követel meg. Egyelôre azonban a döntéshozók vonakodnak radikális lépéseket tenni ezen a téren, miközben a vállalati szféra is az eddig megszokott üzleti megoldásokat részesíti elônyben. Idôvel azonban elkerülhetetlen lesz a szén-dioxid-kibocsátás csökkentése, így a kormányok és a vállalatok minél tovább halogatják az ezen probléma ellen való hatékony fellépést, annál inkább nô majd a kiigazítás költsége. Az új környezetvédelmi szabályozások egyre nagyobb terhet jelenthetnek azon vállalatok számára, melyek közvetve vagy közvetlenül hozzájárulnak a légkör szén-dioxid-kibocsátásának növekedéséhez. Ez akár a túlélésüket is fenyegetheti. Kiernan (2014) szerint a vállatoknak ideig-óráig lehet ugyan halogatniuk a megváltozott környezeti feltételekhez szükséges alkalmazkodást és az ezzel járó átalakulást, de ahogy a klímaváltozás okozta kockázatok egyre nyilvánvalóbbá válnak, úgy gyorsul fel majd az átalakulás üteme, és ezzel együtt nô annak költsége is. Ha a klasszikus ipari megoldásokat használó vállalatok nem kezdik el idóben csökkenteni ökológiai lábnyomukat, akkor idôvel jelentôs kihívással találhatják szemben magukat.

- Fizikai (physical risk) kockázat a brit jegybank definíciója szerint, azaz elsô számú kockázat, mely idôjárással kapcsolatos eseményekból fakad, például az áradások vagy a viharok okozta károk. Ezek egy része okozhat közvetlenül a vállalkozás számára anyagi és fizikai kárt, másrészról pedig beszélhetünk olyan környezeti katasztrófa által bekövetkezett kárról, amely a beszállítói láncban okoz fennakadásokat, károsodást. A Bank of England szerint a klímaváltozás hatására a jövőben jelentôs mértékben növekedik a szélsôséges idôjárási események száma, és azok hatása is pusztítóbb lesz. Ennek megfelelően nagymértékben emelkedik az átlaghőmérséklet, amely hosszú, forró nyarakat eredményez, így megnố az aszállyal sújtott hónapok száma. Ezzel párhuzamosan az északi és a déli jégtakaró olvadása miatt az óceánok vízszintjének az emelkedése várható, miközben az esôzések intenzitása is erôsebb lesz. Az elôbbi veszélyezteti az óceánés tengerpartok mentén fekvó városokat, míg az utóbbi miatt nagyban növekszik az árvizek és áradások valószínúsége is, nem beszélve arról, hogy a jelenlegi előrejelzések szerint a trópusi viharok is gyakrabban előfordulhatnak, amelyek jelentôs károkat 
okozhatnak. Így nem véletlen, hogy a jelentés arra a következtetésre jutott, hogy a természeti környezetben végbemenô alapvetô változások egyre nagyobb hatással lesznek a gazdasági és pénzügyi stabilitásra, illetve veszélyeztetik a pénzügyi vállalatok múködését, biztonságát, mely a jegybankokra nézve is egyértelmú következményekkel jár (Bank of England, 2015b).

- Végül pedig érdemes megemlíteni az úgynevezett felelôsségbiztosításhoz (liability risk) kapcsolódó környezeti és klímaváltozásból fakadó kockázatokat. Ez abban az esetben lép fel, mikor a gazdasági szereplô olyan klímaváltozáshoz vagy környezeti eseményhez kapcsolódó fizikai vagy átmeneti kockázatokból származó károkat szenved el, melyekkel kapcsolatosan a kompenzációt azoktól várja, akik felelôsséget vállaltak a kárért (azaz biztosították azt a felelôsségbiztosítás keretein belül).

2. A társadalmilag nemkívánatos - magas szén-dioxid-kibocsátással és környezetszennyezéssel járó - gazdasági tevékenységek banki hitelezése hitelpiaci elégtelenségnek is tekinthető, ugyanis Campiglio (2016) szerint egyensúlyhiány lép fel a hitelintézetek érdekei - akik a pénzkínálat nagy részét létrehozzák - és a társadalom által kitúzött közösségi célok között. Ezeket „a piaci elégtelenségeket” (azaz az ilyen típusú befektetéseket) hatékony környezetvédelmi politikával és a szén-dioxid árának meghatározásával kellene korrigálni, megelôzni vagy csökkenteni. Addig, amíg ez a két utóbbi eszköz nem látja el kellô hatékonysággal a funkcióját, a jegybankok a rendelkezésre álló eszköztáruk révén befolyásolni tudják a hitelezés alakulását, elôsegítve a megújuló energiaforrások és a zöldberuházások elterjedését.

3. Azon feltörekvô országokban, ahol a környezetvédelmi politika fejletlen, a jegybankok kamatpolitikájuk és a bankszektor felett végzett ellenôrzô szerepük révén befolyásolhatják a befektetési döntéseket. Ebből adódóan a fenntartható fejlôdés és a környezetvédelem számára kevésbé káros beruházások felé irányíthatják a hiteleket. Ez elsôsorban azokban a fejlôdô országokban jelenthet alternatívát, ahol a jegybankok számítanak a leghatékonyabban múködó és a legkifinomultabb állami szervezetnek, így az egyes közpolitikai döntések még nem születtek meg, vagy azok végrehajtása akadozik (UN, 2017).

A rendelkezésre álló monetáris politikai eszközeik révén a központi bankok befolyásolni tudják a pénzügyi piac szereplôinek beruházási és befektetési döntéseit, hatással vannak a hitelezésre, mindennek köszönhetően előtérbe tudják helyezni a zöldberuházások terjedését. Ehhez azonban az szükséges, hogy a jelenleg használt jegybanki eszközök mellett újra alkalmazzák az aktívabb jegybanki politikához kapcsolódó, úgynevezett „nem hagyományos” monetáris politikai eszközöket is:

1. A jegybankok környezetvédelemmel kapcsolatos közzétételi előírásokat szabhatnak meg a pénzpiaci szereplóknek. A klímaváltozással kapcsolatos kockázatok transzparenciájának a növelése elôsegíti azok beárazását és a szükséges tôkeallokációt, továbbá alapját adja a zöld makroprudenciális szabályozásnak és a klímaváltozással kapcsolatos stresszteszteknek is.

2. A makroprudenciális szabályozásoknak számításba kellene venni azokat az externáliákat, amelyek növelik a pénzügyi rendszer instabilitását, és meghatározzák azon környezeti egyensúlytalanságokat, melyek anyagi értelemben vett pénzügyi kockázatot 
okozhatnak. Így a makroprudenciális szabályozások útján mérsékelni lehet a környezetszennyezô vagy magas szén-dioxid-kibocsátással járó beruházások mértékét, például a magas légszennyezettséggel járó gazdasági szektorokban tevékenykedô vállalatok magasabb kockázati besorolásával, vagy az esetleges klímaváltozást számításba vevô stressztesztek alkalmazásával. Továbbá olyan egykoron alkalmazott, unortodox megoldásokat is újra előtérbe kellene helyezni, mint például a hitelplafonok alkalmazása egyes, magas szén-dioxid-kibocsátással járó vagy a környezetet nagyban terhelő szektorokban.

3. A jegybankoknak közvetlenül a zöldgazdaság fejlődését elősegítô hitelpolitikát kellene előtérbe helyezniük. Fry (1995) hat közvetlen hitelpolitikai eszközt jelöl meg, melyekkel elố lehet segíteni a zöldgazdaság fejlesztését: a támogatott hitelkamatlábak a prioritást élvezó szektorokban tevékenykedô vállalatok számára, differenciált rediszkontálási kamatlábak, hitelfolyosók, közvetlen költségvetési támogatások, hitelplafonok alkalmazása és a szakosodott pénzügyi intézmények támogatása.

4. A kevésbé fejlett pénzügyi rendszerrel rendelkezô országok esetében a kötelezó tartalékrátára vonatkozó elôírások révén elôsegíthetố a zöldbefektetések növekedése. Így a privilegizált zöldkötvények esetében alacsonyabb kötelezô tartalékrátákat lehet megszabni, ami lehetőséget ad arra, hogy előtérbe helyezze a zöldberuházásokat a hagyományosakkal szemben. Erre jó példa a Libanoni Nemzeti Bank kezdeményezése, amely 2010-ben alacsonyabb tartalékráta-követelményeket vezetett be a „zöld”-hitelezés terén. Ennek megfelelôen a libanoni jegybank úgy támogatja a zöldhitelezést, hogy a hitel értékének 100-150\%-ával csökkenti a kereskedelmi bankok tartalékrátájára vonatkozó követelményt, amennyiben a kérelmezô bemutatja a Libanoni Energiaközpont által kiállított tanúsítványt, mely bizonyítja, hogy a finanszírozott projekt jelentôs energiamegtakarítással jár (Rozenberg et al., 2013; Campiglio, 2016).

5. A jegybankok a tőkekövetelmények útján is tudják befolyásolni a zöldbefektetések alakulását, ugyanis a minimum tôkekövetelmények vagy a különbözô pénzügyi eszközök kockázati súlyának meghatározása közvetlenül hat a bankok hitelteremtô képességére. A Bázel III. tôkekövetelményeket tartalmazó előírásai például tôkecsökkentési tényezóket helyez kilátásba a kis- és középvállalatok számára nyújtott hitelek esetén, ami azt jelenti, hogy a kkv-k eltérô eljárásban részesülnek a nagyvállalatokhoz képest. Hasonló módon a Bázel III. kockázattal súlyozott tôkemutatóinak a számításait úgy kellene módosítani, amely során az alacsony szén-dioxid-kibocsátással járó tevékenységek alacsonyabb súlyozást kapnának, mint az egyéb befektetési lehetôségek (Campiglio, 2016).

6. A jegybankoknak a mennyiségi lazítás során elôtérbe kellene helyezniük a zöldkötvények felvásárlását. David King, a brit kormány egykori tanácsadója szerint a menynyiségi lazítás célja a zöldgazdaság fellendítése kell hogy legyen (Harvey, 2012). Így a mennyiségi lazítással elő kellene segíteni az energiahatékony infrastrukturális beruházásokat és a megújuló energetikai megoldások még szélesebb körú elterjedését, ezzel párhuzamosan az egész gazdaság eróforrás-felhasználását és annak környezetre gyakorolt negatív hatását csökkenteni lehetne.

7. A jegybankok által a fenntartható fejlődést elôsegítő hitelezési ajánlások, útmutatók, zöldkötvényekkel kapcsolatos szabályok kidolgozása kereskedelmi bankok és intézményi befektetôk számára. 
8. Végül pedig a jegybankok állásfoglalásaikkal, a jegybankelnökök pedig a nyilatkozataikkal, azaz az úgynevezett softpowerrel, ha mérsékelten is, de befolyásolni tudják a pénzpiac szereplőinek viselkedését (Bank of England, 2015a; UN, 2017).

Az ENSZ tanulmánya megjegyzi, hogy bármennyire elkötelezett legyen is egy jegybank a klímaváltozás elleni harcban, semmiféleképpen sem kaphat fószerepet (fóleg, ami a fejlett országok gazdaságát illeti). A klímaváltozás elleni „harc” elsố vonalában elsôsorban ugyanis olyan entitásoknak kell szerepelniük, mint a környezetvédelmi minisztériumok és egyéb környezetvédelemmel foglalkozó hatóságok, a pénzügyminisztérium és a kereskedelmi bankok. A jegybankoknak csupán kiegészítô funkciót kell betölteniük, és a rendszerben részt vevô szereplôk támogatását kell biztosítaniuk (UN, 2017).

Másrészrôl, ha egy jegybank elôtérbe is helyezi a klímaváltozás elleni küzdelmet, az nem mehet a jegybank által kitûzött többi célkitûzés rovására, így a jegybankoknak körültekintôen kell megválasztaniuk az egyes pénzügypolitikai eszközeiket, ha szerepet akarnak vállalni a klímaváltozás elleni harcban.

Bízom benne, hogy a fentiek, ha nem is teljes körú, de széles rálátást adtak arra, hogy milyen közpolitikai eszközök szükségesek ahhoz, hogy felvegyük a harcot a klímaváltozással szemben. Miközben jól mutatják azt is, hogy ez sok esetben a jelenlegi közgazdasági gondolkodással szembemenô, alternatív megoldásokat követel, legyen szó fiskális vagy monetáris politikáról. Mindez nagyban felértékeli az állam és a jegybankok szerepét a gazdaság és a pénzügyek irányítását illetôen, és egy sokkal aktívabb szerepkörrel ruházza fel óket.

\section{FELHASZNÁLT IRODALOM}

Bank of England (2015a): One Bank Research Agenda. Discussion paper, www.bankofengland.co.uk/-/media/ boe/files/research/one-bank-research-agenda--summary.pdf?la=en\&hash=B2C820FBF6A960C4A6 25C2DAB5B5B6CE4FEDF120.

Bank of England (2015b): The Impact of Climate Change on the UK Insurance Sector. A Climate Change Adaptation Report by the Prudential Regulation Authority. Bank of England, London, www.bankofengland.co.uk/-/ media/boe/files/prudential-regulation/publication/impact-of-climate-change-on-the-uk-insurancesector.pdf.

Bloom, Nicholas et al. (2015): Does Working from Home Work? Evidence from a Chinese Experiment. The Quarterly Journal of Economics, Vol. 130, No. 1, 165-218, https://doi.org/10.1093/qje/qju032.

Brock, William A. - Taylor, M. Scott (2004): The Green Solow Model. NBER Working Paper, No. w10557, https://ssrn.com/abstract=557190.

Bureau, Benjamin (2011): Distributional Effects of a Carbon Tax on Car Fuels in France. Energy Economics, Elsevier, Vol. 33, No. 1, 121-130.

Campiglio, Emanuele (2016): Beyond Carbon Pricing: The Role of Banking and Monetary Policy in Financing the Transition to a Low-carbon Economy. Ecological Economics, Vol. 121, 220-230, https://doi. org/10.1016/j.ecolecon.2015.03.020.

Eichengreen, Barry et al. (2011): Rethinking Central Banking. Committee on International Economic Policy and Reform. Brookings, Washington, www.brookings.edu/wp-content/uploads/2016/06/Rethinking-Central-Banking.pdf.

Fry, Maxwell J. (1995): Flexibility in Finance. In: Tony Killick (ed.): The Flexible Economy. Causes and Consequences of the Adaptability of National Economies. Routledge, London, 299-326. 
Gyürüs Máté - Prácser Attila - Csiszár Csaba (2008): Telematikai alapokon múködố car pooling rendszer. http:/ / real.mtak.hu/23484/1/5_19_u.pdf.

Harvey, Fiona (2012): Sir David King: Quantitative Easing Should Be Aimed at Green Economy. The Guardian, 26 June, www.theguardian.com/environment/2012/jun/26/david-king-quantitative-easing-green.

IMF (2011): Olivier Blanchard: Monetary Policy in the Wake of the Crisis. www.imf.org/external/np/seminars/ eng/2011/res/pdf/OB2presentation.pdf.

Khan, Mehran - Chang, Yen-Chiang (2018): Environmental Challenges and Current Practices in China A Thorough Analysis. Sustainability, Vol. 10, No. 7, https://doi.org/10.3390/su10072547.

Kiernan, Peter (2014): Risky Business. The Economist Intelligence Unit, 23 September, https://perspectives. eiu.com/energy/risky-business.

Kutasi Gábor - Perger Júlia (2014): Adóösztönzôkkel az externáliák ellen: A népegészségügyi termékadó és a szén-dioxid-adó nemzetközi példái. Köz-Gazdaság, 9. évf., 4. sz., 109-125.

Olson, Erik L. (2015): The Financial and Environmental Costs and Benefits For Norwegian Electric Car Subsidies: Are They Good Public Policy? International Journal of Technology, Policy and Management, Vol. 15, No. 3, 277-296, https://doi.org/10.1504/IJTPM.2015.071036.

Pataki György - Bela Györgyi - Kohlheb Norbert (2003): Versenyképesség és környezetvédelem. PM Kutatási Füzetek 5., Pénzügyminisztérium, https://tatk.elte.hu/dstore/document/118/1177311411_5_fuz_040107.pdf.

Porter, Michael E. (1990): The Competitive Advantage of Nations. Free Press, New York.

Rozenberg, Julie et al. (2013): Funding Low-carbon Investments in the Absence of a Carbon Tax. Climate Policy, Vol. 13, No. 1, 134-141, https://doi.org/10.1080/14693062.2012.691222.

Sipos Nikoletta (2009): Az adók, díjak, járulékok externális hatásai környezetvédelmi szempontból. Gazdálkodás, 53. évf., 5. sz., 456-459.

Stern, David (2004): The Rise and Fall of the Environmental Kuznets Curve. World Development, Vol. 32, No. 8, 1419-1439, https://doi.org/10.1016/j.worlddev.2004.03.004.

Stern, Nicholas (2007): The Economics of Climate Change. The Stern Review. Cambridge University Press, Cambridge.

Szlifka Gábor (2014): Környezetvédelmi ösztönzôk a magyar adójogban. Pázmány Law Working Papers, PPKE, http://plwp.eu/docs/wp/2014/2014-06.Szlifka.pdf.

The Economist Intelligence Unit (2015): The Cost of Inaction: Recognising the Value at Risk from Climate Change. The Economist Intelligence Unit, www.eiuperspectives.economist.com/sites/default/files/ The $\% 20$ cost $\% 20$ of 20 inaction_0.pdf.

UN (2015): Adoption of the Paris Agreement. Framework Convention on Climate Change. United Nations, https:// unfccc.int/resource/docs/2015/cop21/eng/109r01.pdf.

UN (2017): On the Role of Central Banks in Enhancing Green Finance. United Nations Environment Programme.

Vermeend, Willem - Van der Ploeg, Rick - Timmer, Jan W. (2008): Taxes and the Economy. Edward Elgar Publishing, Cheltenham.

Weisbach, David A. (2012): Should Environmental Taxes Be Precautionary? National Tax Journal, Vol. 65, No. 2, 453-474, https://doi.org/10.17310/ntj.2012.2.07. 